\title{
GLL
}

$0 \square=0$ Geomatics, Landmanagement and Landscape No. 2 • 2021, 39-57

\section{THE USE OF UAV DATA FOR PHOTOGRAMMETRIC DOCUMENTATION}

\author{
Izabela Piech, Artur Borgiasz
}

\begin{abstract}
Summary
Photogrammetry is a rapidly developing field of science, using new technologies such as unmanned aerial vehicles (UAVs) and digital cameras. Currently, unmanned aerial vehicles are not only used for amateur or professional commemorative aerial photos, but also have much more specialized applications. New technologies allow for faster development of numerous fields of science and provide better results with less work and resources. Unmanned aerial vehicles are used for photogrammetric raids, which produce photogrammetric images of terrain surface or buildings. This allows the generation of orthophotos, and even three-dimensional terrain models, enabling further analysis of a research area. The aim of the study was to make an orthophotomap of the cemetery in the Sułoszowa municipality on the basis of data obtained during a drone raid and to compare it with the existing orthophotomap. The goal was planned to be achieved through the following steps: importing images to Agisoft PhotoScan and georeferencing them to ensure metricity of subsequent studies, generating an orthophotomap and a cloud of points mapping the studied area, compilating and comparing the resulting numerical data, as well as graphic data.
\end{abstract}

\section{Keywords}

$\mathrm{UAV} \bullet$ photogrammetric documentation • orthophotomap

\section{Introduction}

In the past, before unmanned aerial vehicles were widespread and would become available for virtually every person, performing raids was much more expensive, laborious and complicated. It was not possible to capture of small objects, such as a cemetery, when taking photos from a plane due to the velocity and altitude of flight. Prepared raid plans covered an area of several dozen square kilometres. The plane needed an airport to take off, and if there was no runway near the photographed area, the plane had to reach to the raid site burning a lot of fuel. With the development of this technique, increasing number of new drone designs were created. Engineers were competing for better, faster, more efficient, and at the same time cheaper designs. Currently, the purchase of a small amateur drone is within the reach of almost every- 
body. These are, however, less advanced designs than the models used for raids by surveyors, not to mention the unmanned aerial vehicles used by institutions such as the military or NASA, which can cover tens of thousands of kilometres and cost several million dollars [Bielawski 2015]. In Poland, unmanned aerial vehicles (UAV) are commonly referred to as drones. The term is mainly used colloquially, but can be often also found in scientific journals. The name is derived from the English word drone [http://sjp.pwn.pl/poradnia/haslo/dron-czy-drona;12666.html], which refers to the sound that unmanned aircrafts make. In the literature and the legislation, there are still many different terms for UAV, some formerly used, such as an unmanned flying vehicle or a non-pilot aircraft [Rozporządzenie Ministra Infrastruktury z dnia 15.07.2003] for the flying vessel itself. Also in use is the unmanned flying system or the unmanned aerial system (UAS) or the unmanned aerial platform [Cwojdziński 2013], and other rare modifications to these expressions, when a system consists of a drone, a control system, a connection to control the drone and other equipment [http://www. swiatdronow.pl/slownik (15.05.2017)]. Similarly, in English, there are several different phrases used interchangeably to the term UAV, such as: RPA (remotely piloted aircraft), RPAV (remotely piloted aerial vehicle), as well as for UAS e.g. UAS (unmanned aircraft system), UAVS (unmanned-aircraft vehicle system), RPAS (remotely piloted aircraft system). In Poland, however, it is correct to use the phrase unmanned aerial vehicles directly derived from the translation of the English version - UAV, generally accepted in science and technology for the definition of the group of vessels in question [Maj-Marjańska and Pietrzak 2011]. Nevertheless, it should be noted that some Polish written sources also use English terminology (UAV, UAS), as it is accepted in many European countries. There is no definition of UAV in the Polish law, the Aviation Law Act says only that "unmanned aerial vehicles may be operated in Polish airspace" [Prawo lotnicze z dnia 3.07.2002, Dz.U. z 2002 r. Nr 130, poz. 1112, as amended). However, several definitions function within the scientific or military community. According to Major Gen. Dr Leszek Cwojdziński, former Chief of the Inspectorate for Implementation of Innovative Defence Technologies of the Ministry of Defence, an unmanned aircraft can be defined as "a driven air object that does not carry the operator, uses aerodynamic forces to provide the vehicle with lifting capacity. It can fly alone or be remotely piloted. It serves as a single-use object or multiple-use, recoverable after the flight" [Cwojdziński 2013]. In turn, according to an analysis conducted by Capt. Dariusz Becamer [Becamer 2007], the most accurate is the definition of the Academy of National Defence, which says that UAV is "an apparatus with and without crew on board. For sustaining in the air, it may use the aerodynamic lift created by aerodynamic laws, on fixed (wings) or mobile lifting surfaces (rotors) or the force of aerostatic current (aerostat). It can be controlled by autonomous systems or remotely by an operator (from the ground, air or ship). It is designed to return and be reused. It may be a single-use aircraft" [Karpowicz and Kozłowicz 2003]. In the literature there are many different divisions of unmanned designs due to parameters such as weight, flight altitude, range. One of the main and general divisions is classification by the purpose of the machine [Burdziakowski 2016]. 
The range of applications of unmanned aerial vehicles is very wide. Due to the low purchase and operating costs compared to manned ships and the high manoeuvrability and ease of small UAV and micro UAV, they are used in many projects that do not require long preparation and high financial resources [Sawicki 2012].

\section{Research area}

The analysed object was the parish cemetery in the municipality of Sułoszowa, in the Kraków poviat, in the Małopolskie Voivodeship.

Large part of the municipality lies in the buffer zone of the Ojców National Park. These are mountainous areas, with a very large height differences of terrain, which should receive special attention while designing a raid plan and its ceiling at which photos can be taken. Cemetery lies secluded near the Sułoszowa municipality (Fig. 1). There are no buildings nor power lines in the vicinity of the cemetery. There are no obstacles in the photographed area that would increase the raid's risk. The cemetery itself is about 2 ha, however to cover the entire area over 3 hectares had to be photographed.

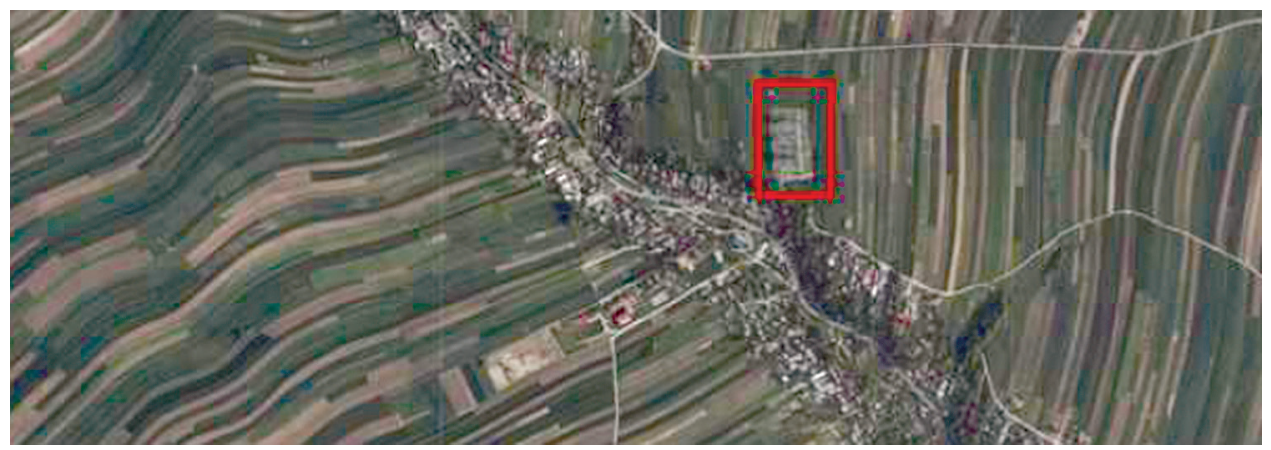

Source: Borgiasz [2020]

Fig. 1. Location of the cemetery

\section{Photo acquisition process and photopoints measurement}

In the first step, the photopoints in the analysed area were marked and measured. In places where it was possible, white squares were painted, while stakes with white squares of paper were hammered onto the arable land. Photopoint measurements were made by the GNSS method, using the Trimble R8 receiver. The next stage of work was the execution of the raid plan. Its proper execution is very important as the success of the entire mission depends on it. During the design process, parameters such as turning points, shutter points, flight velocity and ceiling are determined. Before the execution of the plan, a field inspection was necessary to verify the existence of tall objects, such as trees, that could be unmarked in the map. When designing the take-off 
site, it is necessary to take into account the difference in terrain height, because during the flight the drone does not change its ceiling in relation to changes of ground altitude, but remains at the level set in the raid plan. In addition, "the range of the UAV, the sensor that the desired field pixel is equipped with (mainly the size of the matrix and lens parameters), and longitudinal and transverse coverage of the photographed area should be taken into account" [Piech 2018].

The DJI Ground Station 4.0.11 program was used to design the cemetery raid plan, due to its intuitive interface, easy to use and with wide range of possibilities (Fig. 2).

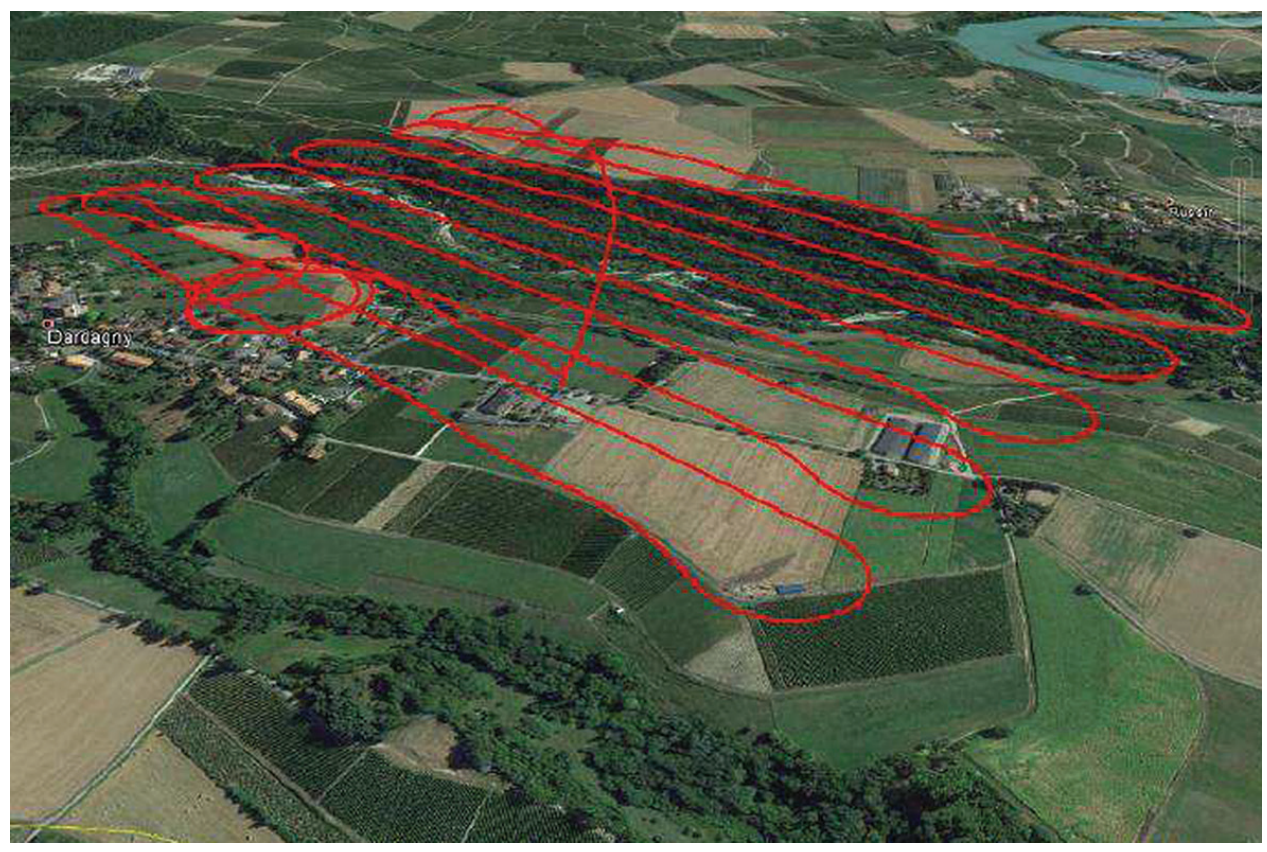

Source: Borgiasz [2020]

Fig. 2. An exemplary raid plan made in DJI Ground Station 4.0.11

The take-off site was designated on a hill to avoid fight's altitude changes in relation to the ground and its slope. There are tall trees in the cemetery area, therefore the flight altitude was set at 50 meters. The raid over the cemetery was made on 24 April 2018. A DJI S1000 unmanned aerial vehicle was used, equipped with a Sony Alfa ILCE-7R camera with a $35 \mathrm{~mm}$ lens. During the measurement, the atmospheric conditions were favourable, the wind reached at gusts up to $5 \mathrm{~km} / \mathrm{h}$, the weather was sunny. The raid resulted in 109 photos, with 30 visible photopoints (Fig. 3). 


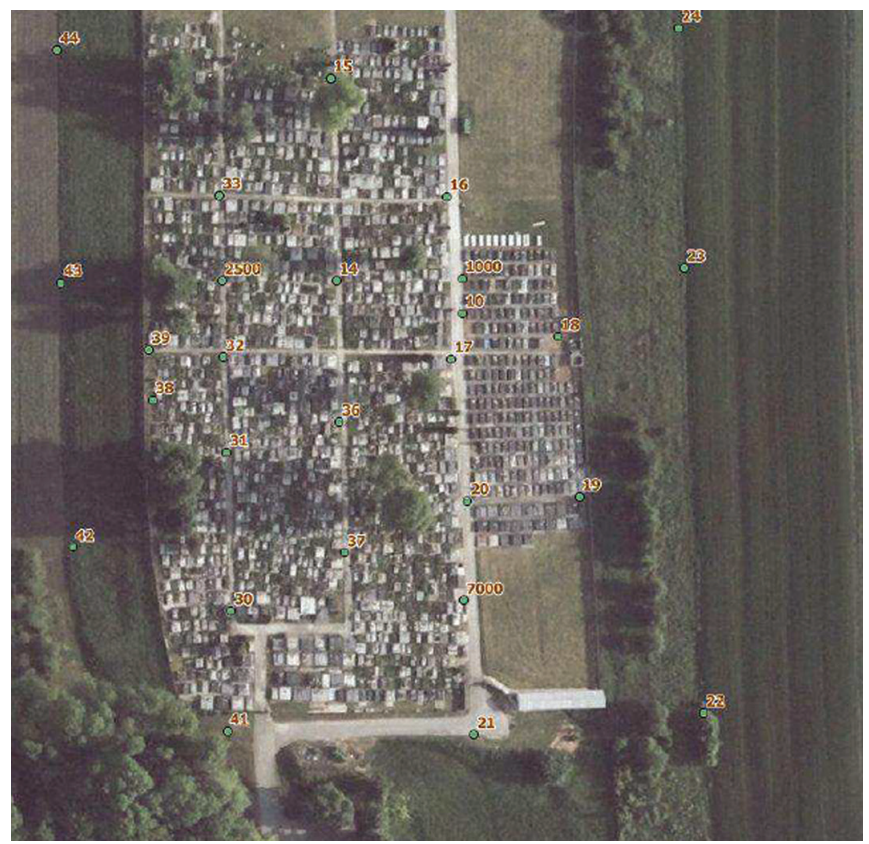

Source: Borgiasz [2020]

Fig. 3. Location of photopoints in the cemetery

\section{Photo processing in the computer software}

The next stage aimed at generating an orthophotomap from the acquired images. Agisoft Photoscan was used for this purpose. The software builds high-quality3D models from normal images, provides exact alignment and does not require special photo frames. It enables photo matching, generates a point cloud from photos, polygon models and texture mapping [http://www.softx.pl].

The first step is alignment. It includes air triangulation (AT) and beam block adjustment (BBA). At this stage, Metashape looks for focal points in images and aligns them with each other. The program also recognizes the position of the camera for each image and improves the calibration parameters of the camera.

The result of these activities is the visualization in the form of a sparse point cloud and a list of camera positions. The sparse point cloud is not directly used in further processing. However, it can be exported for further use in external software. In turn, the compilation of camera positions is required for further $3 \mathrm{D}$ surface reconstruction.

After setting the alignment parameters, a sparse point cloud was created (Fig. 4).

After obtaining a sparse point cloud, a file with the coordinates of the photopoints determined in the field by the GNSS measurement method in the coordinate system ETRS89/Poland CS2000 zone 7 (EPSG: 2178) was uploaded to the program. When uploading the photos, it is important to select an appropriate coordinate system for 


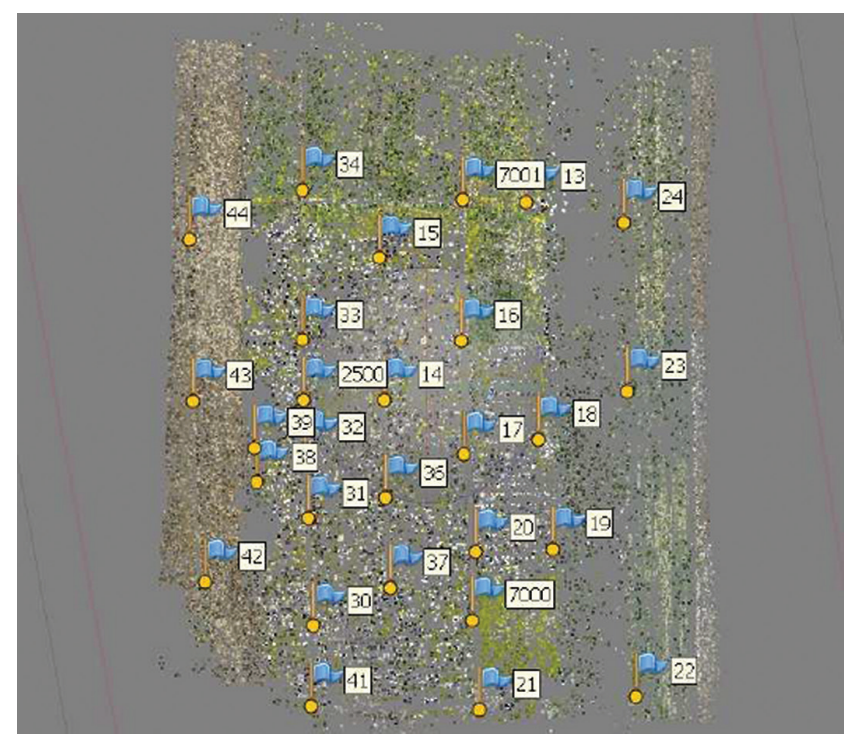

Source: Borgiasz [2020]

Fig. 4. Generated sparse point cloud

the photopoints. After this stage, the research proceeded to the most labour-intensive task of the whole study. At this stage every photopoint was assigned to its image in all photos, on which it was located. Correct realisation of this task was crucial for the whole project. If points are not correctly positioned, the entire orthophotomap will be generated erroneously. For the correct location of a photopoint, it is necessary to insert it in the centre of the sign with which it is marked in the field. These were white squares in this project, and photopoints were inserted precisely in their centre (Fig. 5).

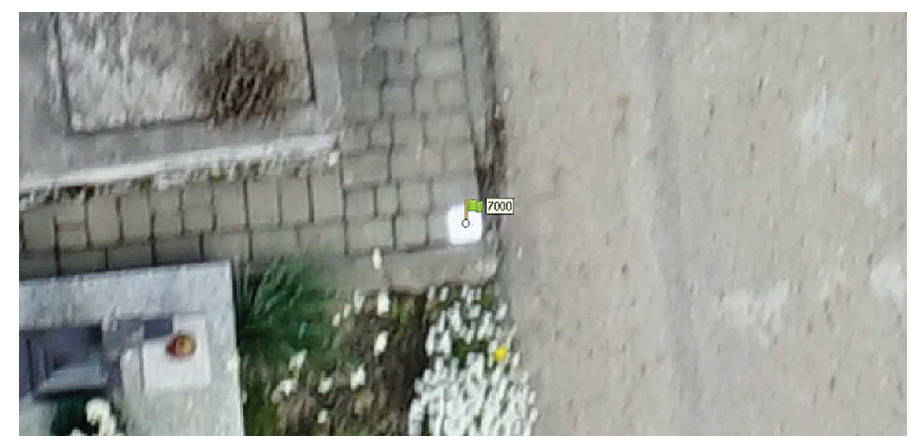

Source: Borgiasz [2020]

Fig. 5. View of a correctly inserted photopoint 
The flags shown in the photo indicate that a photopoint was inserted on all pictures on which it is visible (Fig. 6). Then, in each photo there also appears a corresponding designation indicating that there is no photopoint on the picture which would not have been marked (Fig. 7).

The markings on the images are clearly visible so that looking through the list of images clearly highlights those that need to be checked again. After opening a respective image, points that have already been inserted in another image, but not yet in the selected one, are marked with a grey sign (Fig. 8). When on each image all points are

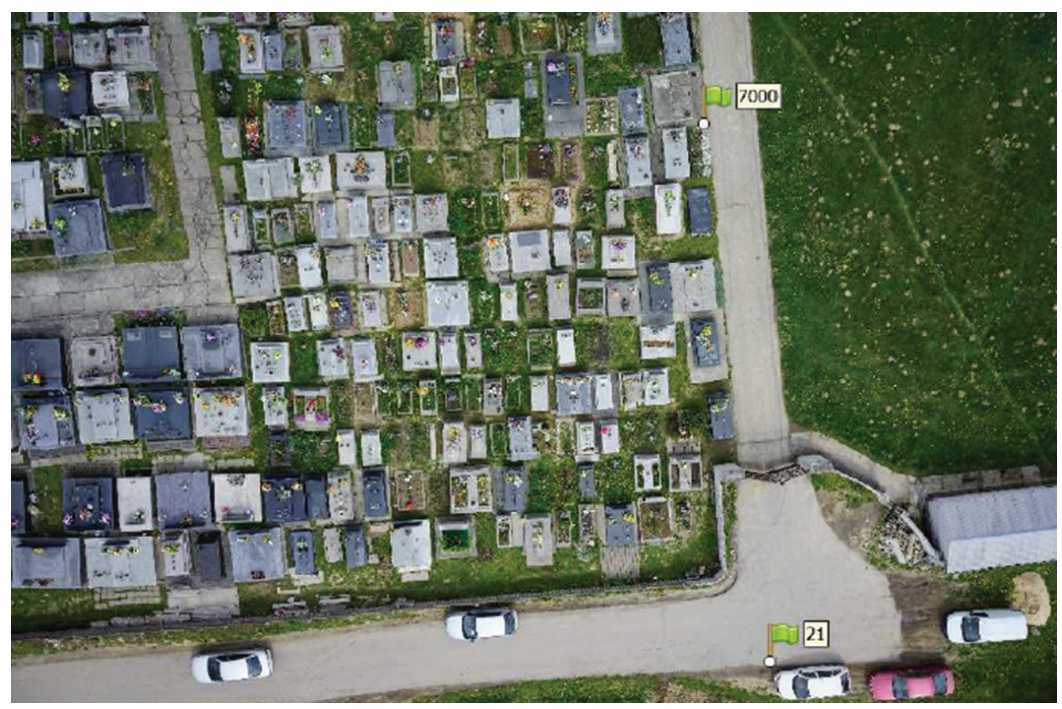

Source: Borgiasz [2020]

Fig. 6. View of photopoints on the relevant points
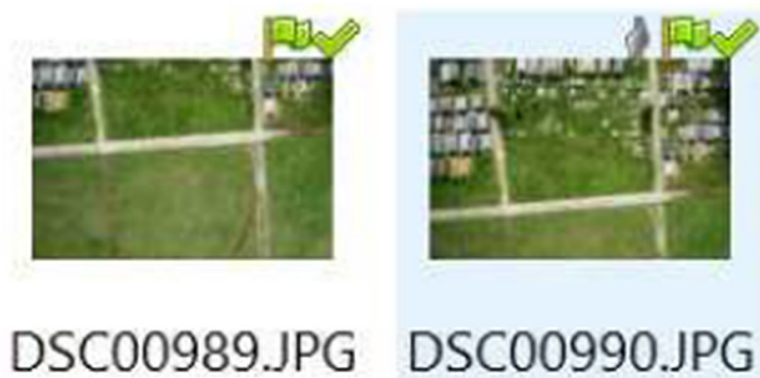

Source: Borgiasz [2020]

Fig. 7. On the left, image on which there are no unassigned points, on the right there is an unassigned point 


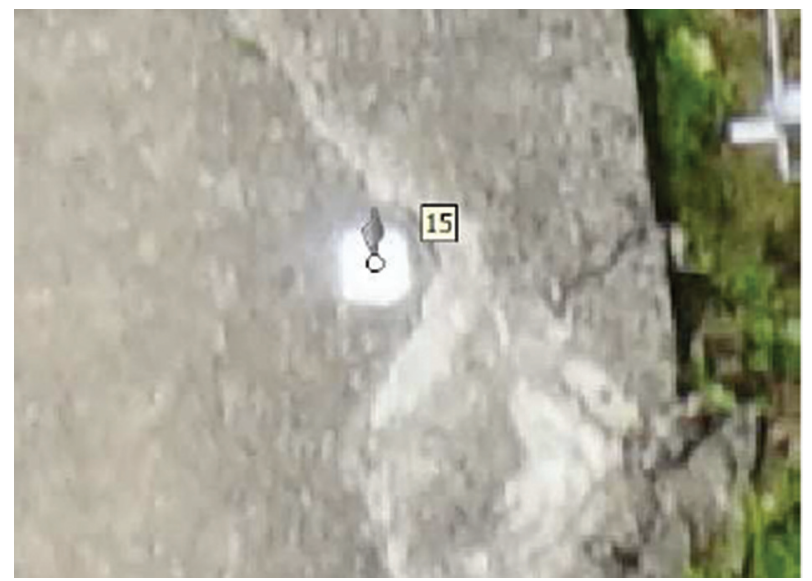

Source: Borgiasz [2020]

Fig. 8. View of an unassigned photopoint

marked, the position errors of the points within the set limits should be checked. If they are fine, a check of the accuracy of the marker's positioning on a given point on each image on which it is located is needed. If the errors are within the specified limits, you can proceed to the next step, which is to generate a report. The report contains all information about operations carried out so far and parameters of the images taken, such as number of images, flight altitude, camera model, location errors of individual photopoints, number of all cloud points, time of merging adjacent images and many others. It also includes the Numerical Terrain Model, a map of the locations of the images and their overlaps, an image of the mean vector of the reprojection error for pixels in the respective cells, a map of photopoints with visualisation of their error directions. Table 1 shows the RMSE measurement error.

Root Mean Square Error (RMSE): The RMSE is a quadratic point-scoring rule that also measures the mean error rate. It is the square root of the mean of the squared differences between the prediction and the actual observation (Equation 1).

$$
R M S E=\sqrt{\frac{1}{n}} \sum_{j=1}^{n}\left(y_{j}-\breve{y}_{j}\right)^{2}
$$

Generating the report is not the last stage of the work. After inserting the photopoints in all images, in which they appear, a dense point cloud has to be generated. For this purpose, "Build dense cloud" function from the "Workflow" tab was applied. As with the sparse point cloud, here also it is necessary to select appropriate settings. The process involves comparing overlapping images to find common features. As a result, a dense point cloud is produced (Fig. 9). After setting the appropriate processing parameters, the operator's role ends and the matching algorithms start working. 
Table 1. RMSE measurement errors

\begin{tabular}{|c|c|c|c|c|c|}
\hline Label & $\mathrm{X}$ error $[\mathrm{cm}]$ & Y error $[\mathrm{cm}]$ & $\mathrm{Z}$ error $[\mathrm{cm}]$ & Total $[\mathrm{cm}]$ & Image [pix] \\
\hline 13 & -0.301663 & 1.36869 & 0.425854 & 1.46481 & $0.259(3)$ \\
\hline 14 & 1.59526 & -2.36224 & 0.0169809 & 2.8505 & $0.098(3)$ \\
\hline 15 & -0.674992 & -1.5226 & 0.170046 & 1.67417 & $0.017(3)$ \\
\hline 16 & -0.737498 & -0.544471 & -0.587826 & 1.08899 & $0.195(7)$ \\
\hline 17 & -1.13296 & -1.43153 & 0.425233 & 1.87449 & $0.134(7)$ \\
\hline 18 & -1.69292 & -0.983407 & -1.18795 & 2.29004 & $0.411(3)$ \\
\hline 19 & 0.111055 & -0.443359 & 0.563198 & 0.725322 & $0.446(4)$ \\
\hline 20 & 1.92418 & -0.766097 & 0.770169 & 2.20965 & $0.223(8)$ \\
\hline 21 & 1.65265 & 0.940782 & 0.540598 & 1.97701 & $0.062(5)$ \\
\hline 22 & -0.293222 & 0.16824 & -0.0785941 & 0.347075 & $0.057(3)$ \\
\hline 23 & 0.162407 & -0.45213 & 0.0189102 & 0.480786 & $0.012(3)$ \\
\hline 30 & 1.35208 & -0.632141 & -1.98685 & 2.48501 & $0.098(9)$ \\
\hline 31 & -1.37686 & 0.320461 & 0.193731 & 1.42688 & $0.094(8)$ \\
\hline 32 & -0.858563 & -1.50681 & -1.18642 & 2.10124 & $0.211(8)$ \\
\hline 33 & -0.782783 & 0.179927 & 0.571322 & 0.985663 & $0.090(6)$ \\
\hline 34 & -0.195049 & 1.38464 & -0.173554 & 1.40904 & $0.098(6)$ \\
\hline 36 & -0.811786 & 1.44492 & 0.479815 & 1.7254 & $0.053(5)$ \\
\hline 37 & -1.97911 & 2.7832 & 0.928464 & 3.53909 & $0.048(7)$ \\
\hline 38 & 1.1217 & 1.59101 & -0.690762 & 2.06559 & $0.212(8)$ \\
\hline 39 & -2.96779 & 2.62401 & 2.23426 & 4.54809 & $0.230(4)$ \\
\hline 41 & -1.69763 & 0.165265 & 0.854271 & 1.90763 & $0.052(4)$ \\
\hline 42 & 2.80297 & 0.767721 & 0.758294 & 3.00351 & $0.933(4)$ \\
\hline 43 & 1.69972 & 0.0709699 & -0.118291 & 1.70531 & $0.234(3)$ \\
\hline 44 & 0.416583 & 1.48608 & -0.135013 & 1.54926 & $0.253(3)$ \\
\hline 2500 & -0.275125 & -0.882058 & -0.146598 & 0.935528 & $0.141(7)$ \\
\hline 7000 & 3.8822 & -3.28121 & -1.68465 & 5.35499 & $0.073(8)$ \\
\hline 7001 & -0.871837 & -0.423789 & -0.371 & 1.03795 & $0.218(6)$ \\
\hline Total & 1.53726 & 1.40782 & 0.860706 & 2.25521 & 0.233 \\
\hline
\end{tabular}

X - Easting, Y - Northing, Z - Altitude Source: Borgiasz [2020] 
This process takes up to several hours in most cases. The processing time depends on the number of images, the size of the area, selected settings and the computational power of the computer.

After creating a dense point cloud, the resulting image begins to resemble an orthophotomap. However, a classification is needed to assign field objects to appropriate groups, for example, select all buildings around their contours and assign them to the group "buildings". In the case of vegetation, 3 classes are distinguished in terms of their height (low vegetation, medium vegetation, high vegetation), which makes it difficult to distinguish between tall and low trees or thickets. Another case are graves, which were not classified due to their number and high percentage of the total area (in the entire area) of the cemetery. After classifying the point cloud, the next stage is generating the Digital Terrain Model (Fig. 10), which is a numerical representation of the topographic height of the terrain surface with an algorithm that enables its determination at any point. Before starting generating, it is important that only points classified as ground are used for building the model, because generating a model including trees or buildings would significantly disturb the final effect. Therefore, accurate assignment of field objects to appropriate groups is essential.

On the attached part of the DTM (Fig. 10), in the shading places, a mesh of triangles that compose the model is visible. Neighbouring points are connected with each other

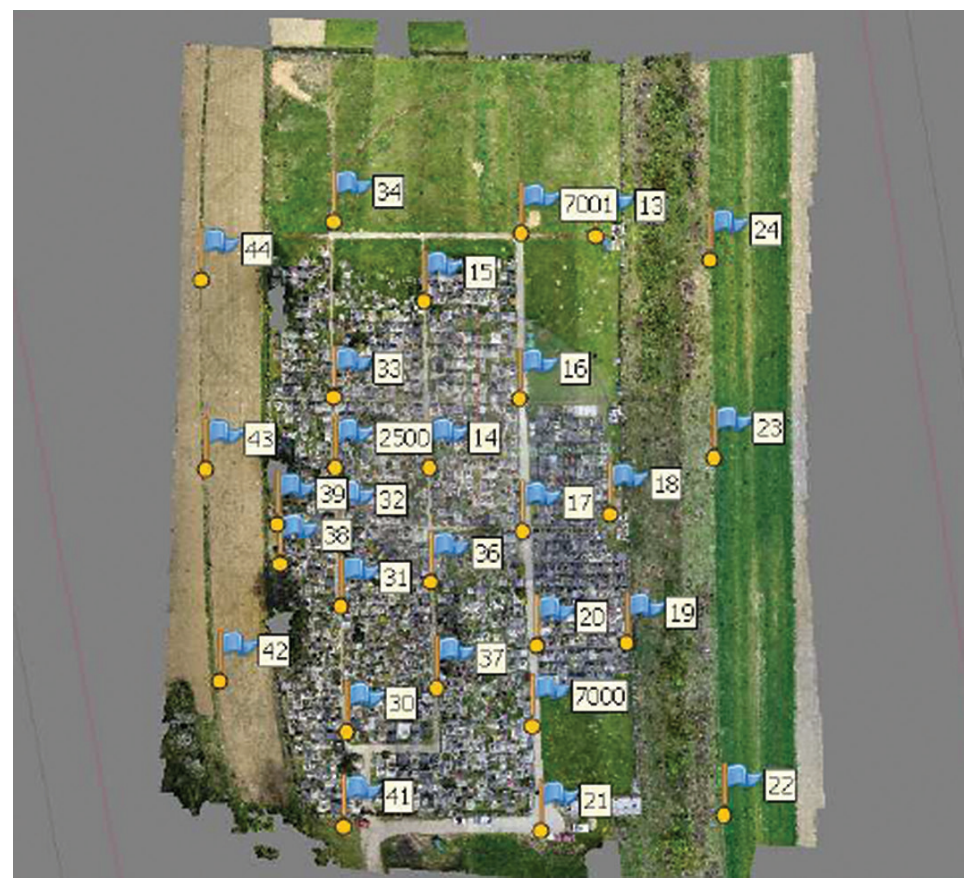

Source: Borgiasz [2020]

Fig. 9. Example of a dense point cloud 
by lines, which enables to interpolate the height of any point, similarly to manual interpolation when drawing contours. Next, in order to reduce the visibility of the triangles mentioned earlier, the mesh should be smoothed with the "smooth mesh" function. A window appears here, which allows to define the degree of smoothing. The higher the number entered, the less visible the triangles will be. Figure 10 shows DTM before smoothing, while Figure 11 shows the mesh smoothed by factor of 10 .

The next step is to build the texture by selecting the "workflow" tab, then the "build texture" function. Texturing is a technique most often used in computer graphics. which allows for faithful reproduction of the actual appearance of the tested 3D model. After this step, once again in the "workflow" tab there is the "build orthomosaic" function, which has to be selected. This will allow to generate an orthomosaic. After checking the

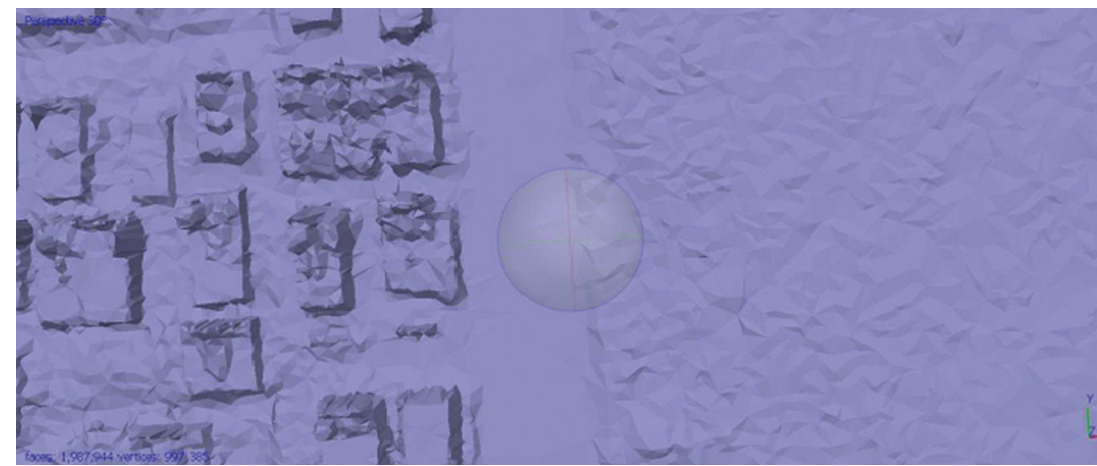

Source: Borgiasz [2020]

Fig. 10. Fragment of the Digital Terrain Model

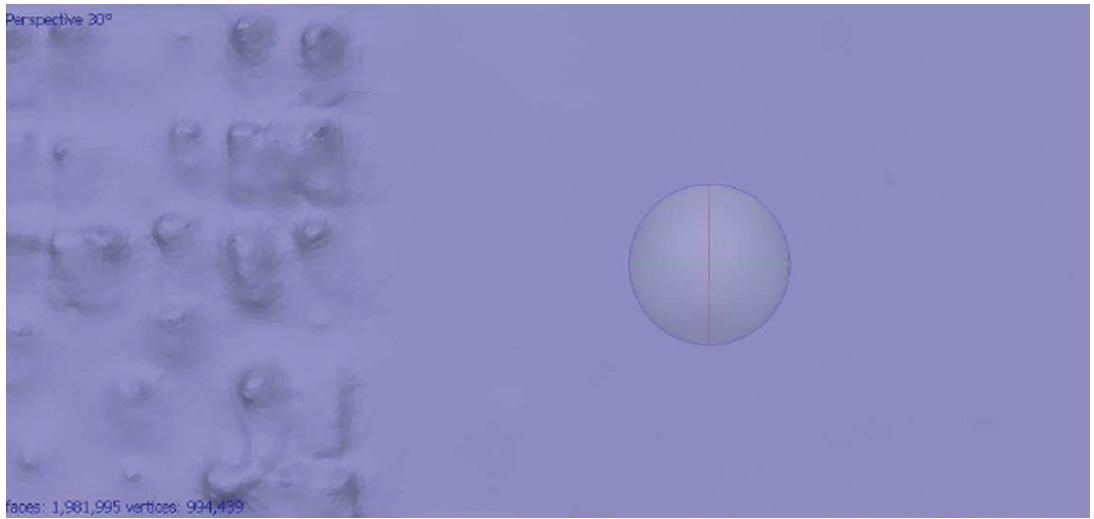

Source: Borgiasz [2020]

Fig. 11. Fragment of the Digital Terrain Model after smoothing the mesh (TIN) 
shifts in the interface of the images and correcting them if necessary, the orthomosaic should be refreshed. If the corrected errors have disappeared and there are no more errors, the created orthomosaic is ready to be exported, eventually forming an orthophotomap (Fig. 12).

During the analysis of orthophotomaps, many changes are visible, some of them are marked with red lines and numbers in Figure 12. Figures from 14 to 24 present approximate fragments, which include both the previous state and the current state as of 24 April 2018.

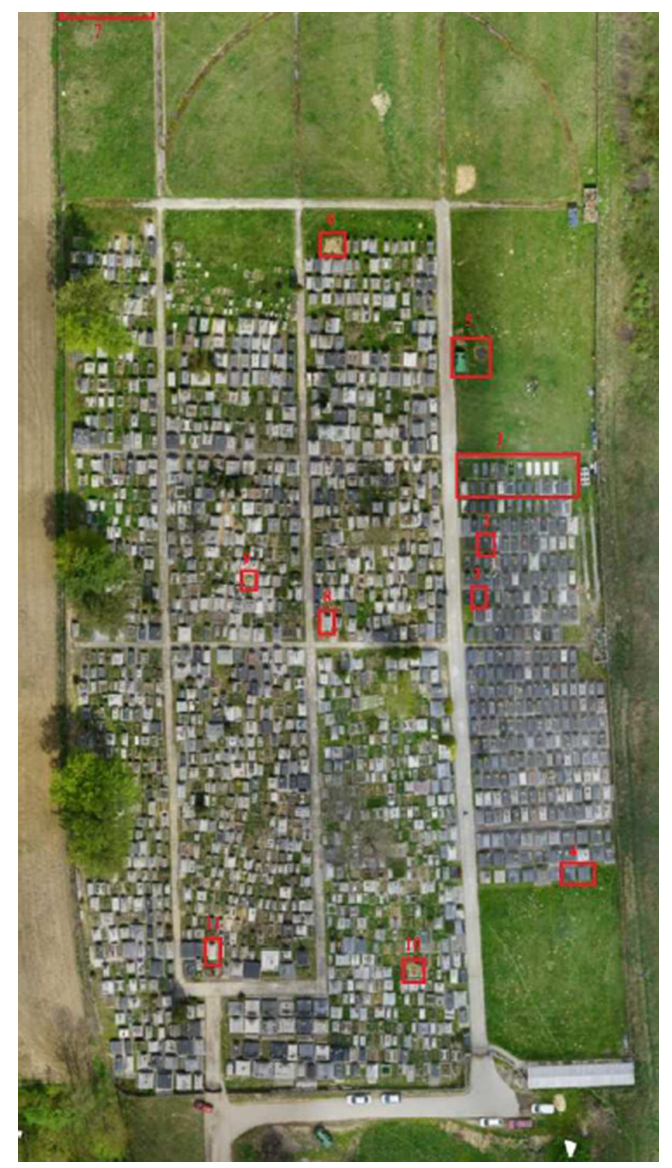

Source: Borgiasz [2020]

Fig. 12. Orthophotomap of the cemetery with marked places of changes 


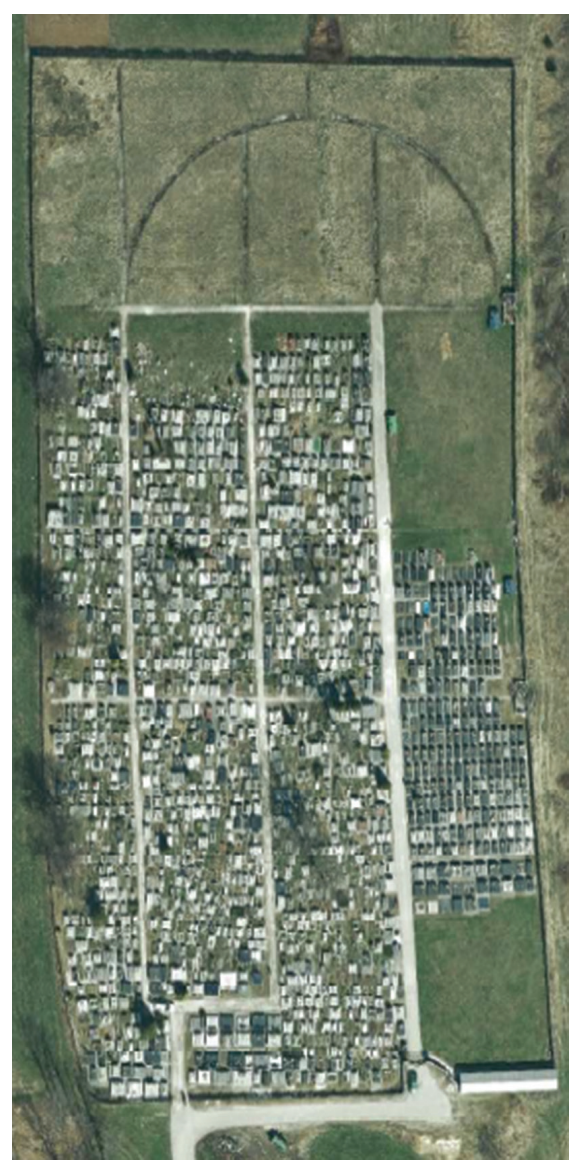

Source: Borgiasz [2020]

Fig. 13. Existing orthophotomap
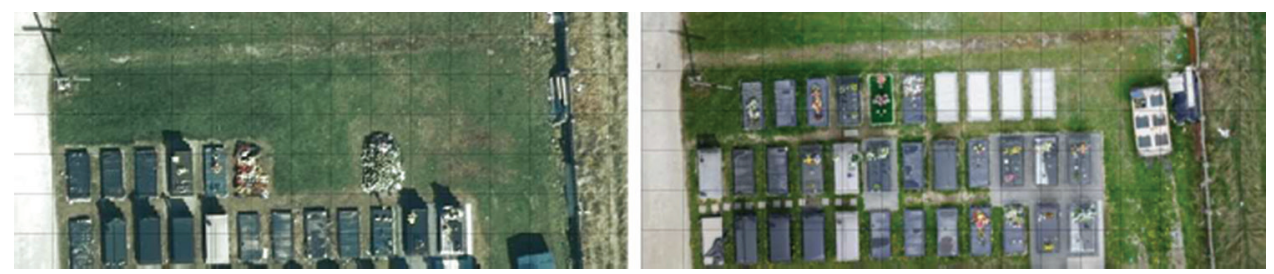

Source: Borgiasz [2020]

Fig. 14. Fragment 1 (previous status on the left, current status on the right) 

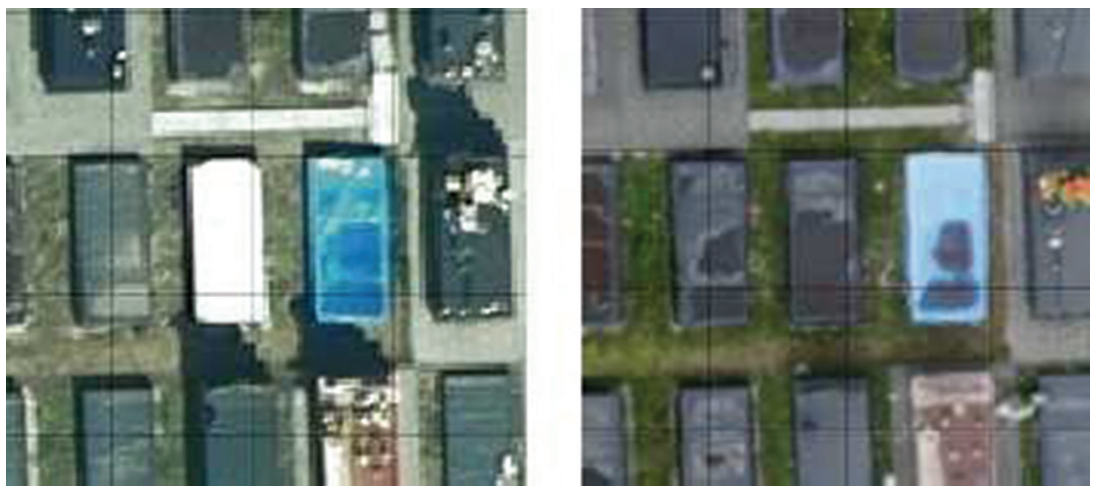

Source: Borgiasz [2020]

Fig. 15. Fragment 2 (previous status on the left, current status on the right)
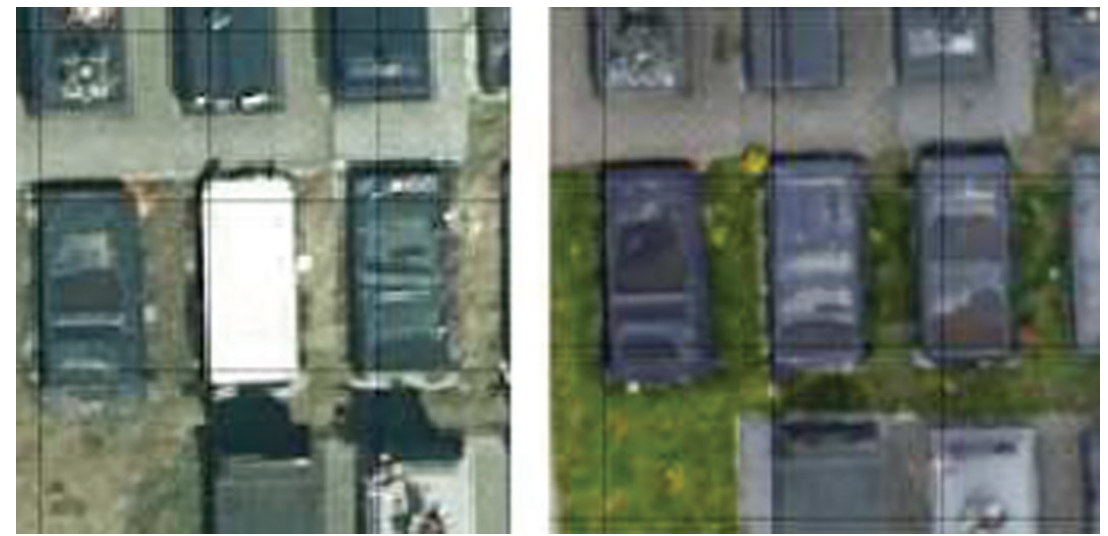

Source: Borgiasz [2020]

Fig. 16. Fragment 3 (previous status on the left, current status on the right)
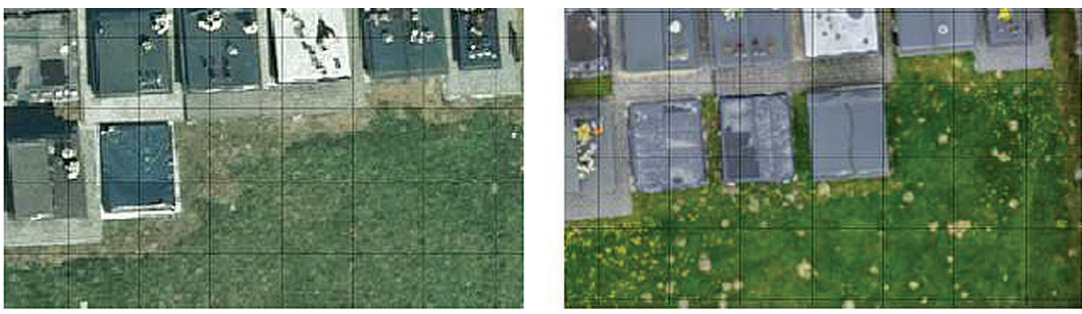

Source: Borgiasz [2020]

Fig. 17. Fragment 4 (previous status on the left, current status on the right) 
In the fragment 5 (Fig. 18) visible changes are a dark circle, which is probably the remains of a bonfire at this location, and a light-coloured square next to a waste container. A light colour indicates dried grass, suggesting that the container has been moved.

The fragments marked with numbers 1, 4, 6 (Fig. 12, 13, 19) show changes in the number of graves, thus on their basis it is possible to notice that new quarters are created in eastern part of the cemetery. Figures 14 and 17 show new tombstones that did not exist when images were taken for the previous orthophotomap.

Fragments 8 to 11 (Fig. 21-24) show changes in the forms of the tombstones, some of them were mounded graves turned into monuments, while others were changed in the opposite direction. Moreover, taking notice of the state of nature, it can be suggested that the images for the orthophotomaps were taken at other times of the year. The existing orthophotomap is based on images taken in late autumn or early spring, as evidenced by the state of nature. There are also visible changes in the number of shrubs and the condition of the sidewalks. In addition, felled trees can be seen behind the eastern wall of the fence, which have been replaced by low vegetation on the new orthophotomap.
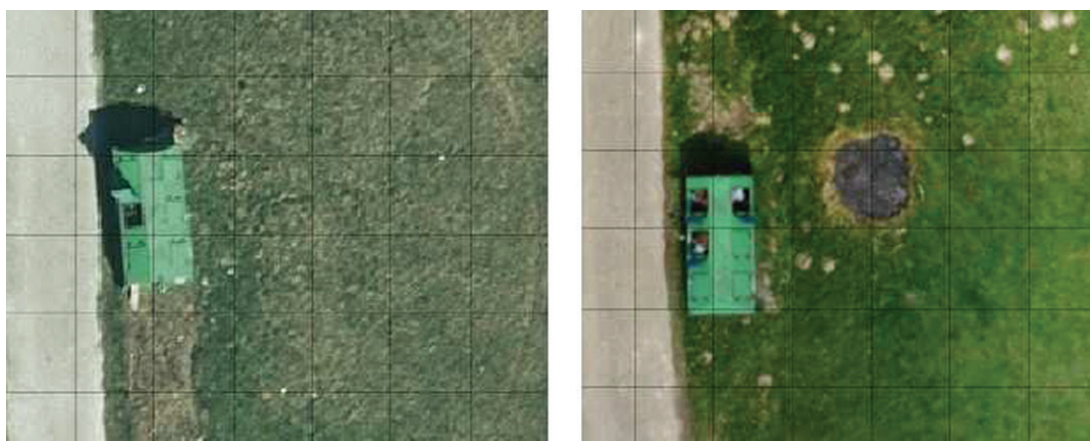

Source: Borgiasz [2020]

Fig. 18. Fragment 5 (previous status on the left, current status on the right)
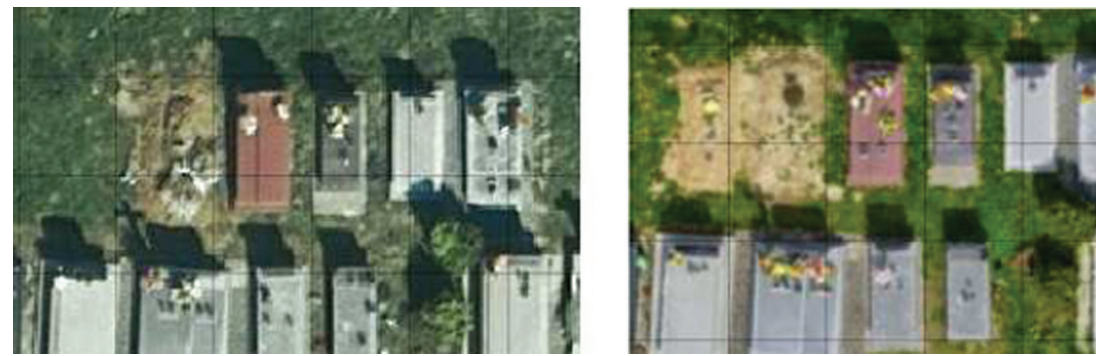

Source: Borgiasz [2020]

Fig. 19. Fragment 6 (previous status on the left, current status on the right) 

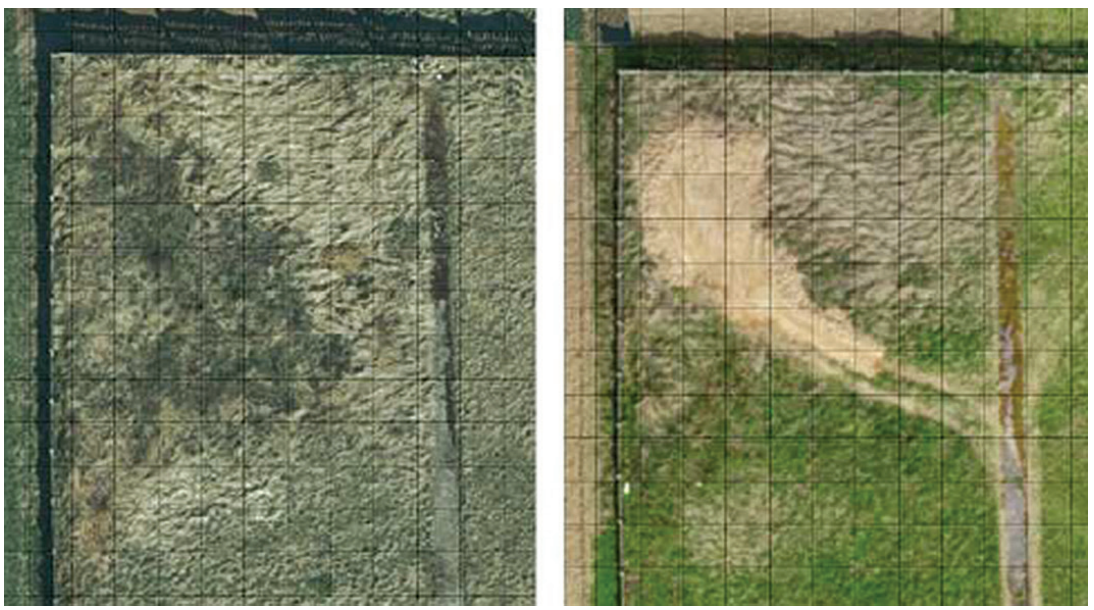

Source: Borgiasz [2020]

Fig. 20. Fragment 7 (previous status on the left, current status on the right)
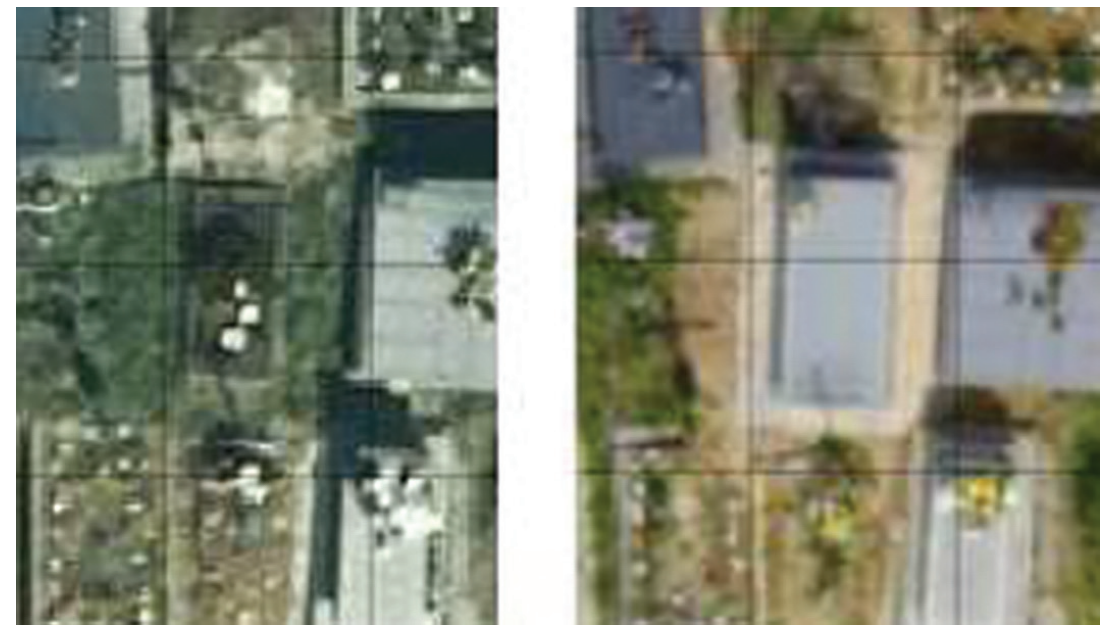

Source: Borgiasz [2020]

Fig. 21. Fragment 8 (previous status on the left, current status on the right) 

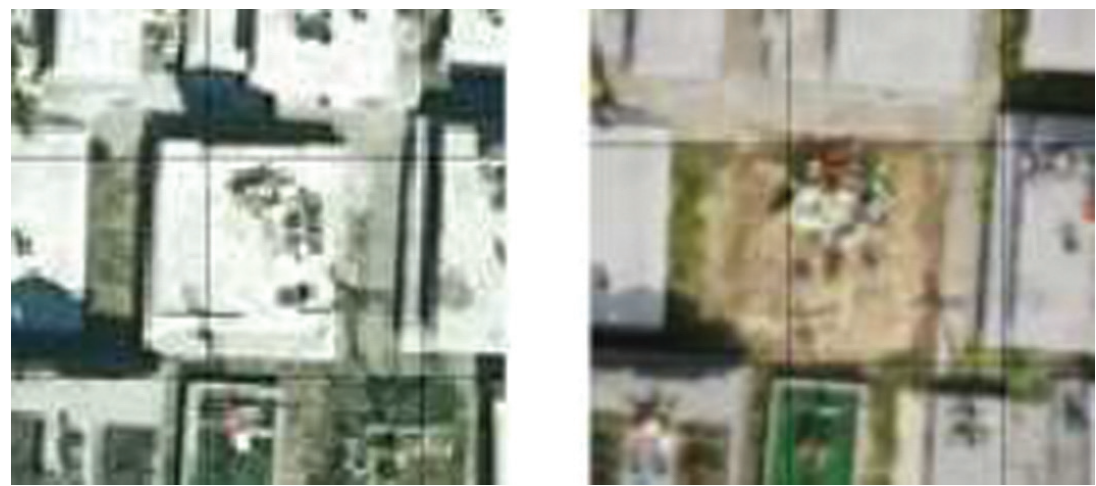

Source: Borgiasz [2020]

Fig. 22. Fragment 9 (previous status on the left, current status on the right)
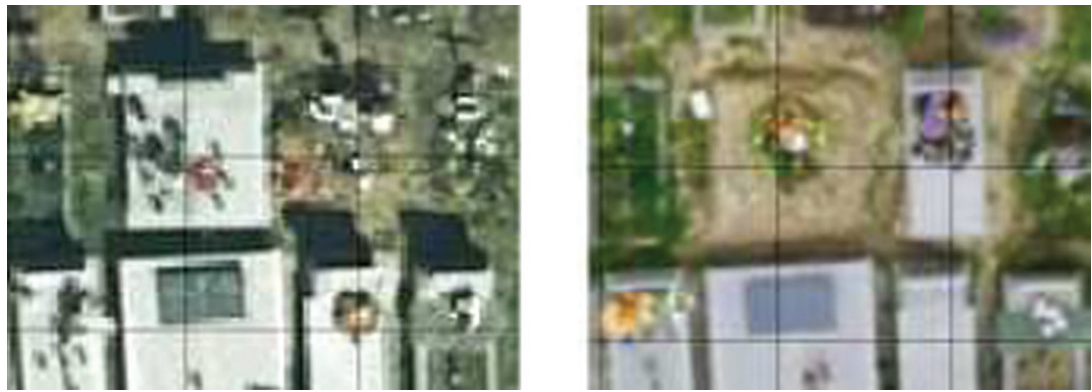

Source: Borgiasz [2020]

Fig. 23. Fragment 10 (previous status on the left, current status on the right)
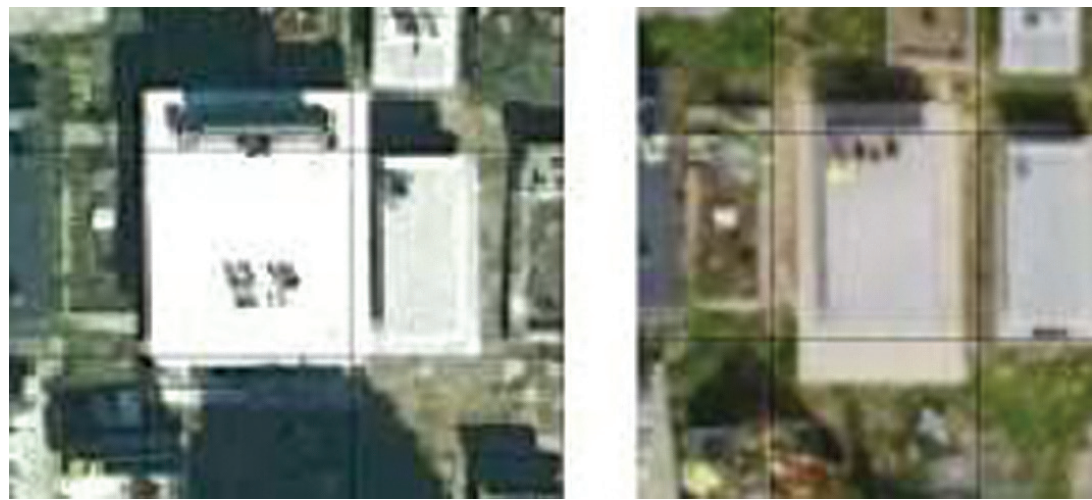

Source: Borgiasz [2020]

Fig. 24. Fragment 11 (previous status on the left, current status on the right) 


\section{Conclusions}

The aim of the study was to make an orthophotomap of the cemetery in Sułoszowa and to compare it with the existing orthophotomap provided by the Agricultural University in Kraków. The data were obtained from the Central Geodetic and Cartographic Documentation Centre in 2012.

Developing an orthophotomap based on UAV images and comparing it with the existing one is a complicated process that requires many stages of work, such as taking photos, developing models, and the inventory process with an analysis of its results. In the course of this study, an attempt was made to realise each of these stages and to compare and interpret the obtained results. The dynamic development of new technologies has a great impact on both the hardware and software used. Drones, which a dozen or so years ago were almost exclusively used for military purposes, due to miniaturization and lower production costs, are available to everyone. The combination of low costs and multiple applications have led to a rapid increase in their popularity. In the field of geodesy, they are primarily used to obtain data for photogrammetry, constituting an economic alternative to aerial photogrammetry. Computer software allows to create various models based on UAV photos, both in 2D and 3D technology. Additionally, the automation of most processes limiting the role of the operator of the selection of parameters of the generated models. This not only facilitates the research of experienced users, but also allows people who have less knowledge in the field of photogrammetry to perform their own drone raid.

\section{References}

Becamer D. (2007). Bezzałogowe systemy latające klasy I-II w przyszłym systemie walki. Zeszyty Naukowe Wyższej Szkoły Oficerskiej Wojsk Lądowych, 1(143), 33-35.

Bielawski R. (2015). Wybrane zagadnienia z budowy statków powietrznych. Definicje, pojęcia i klasyfikacje. Warszawa.

Burdziakowski P. (2016). Przegląd budowy i funkcjonalności współczesnych bezzałogowych statków powietrznych do celów fotogrametrycznych. Biuletyn WAT, LXV, 4.

Cwojdziński L. (2013). Klasyfikacja oraz zasady eksploatacji bezzałogowych platform latających. Motoszybowce.pl, 3-4, 30-32.

Karpowicz J., Kozłowicz K. (2003). Bezzałogowe statki powietrzne i miniaturowe aparaty latające. Akademia Obrony Narodowej, Warszawa.

Maj-Marjańska J., Pietrzak P. (2011). Prawne aspekty użytkowania bezzałogowych statków powietrznych. Bezpieczeństwo Narodowe, II/18, 197-204.

Piech I. (2018). Pozyskiwanie danych przestrzennych z użyciem UAV.

Sawicki P. (2012). Bezzałogowe aparaty latające UAV w fotogrametrii i teledetekcji - stan obecny i kierunki rozwoju. Archiwum Fotogrametrii, Kartografii i Teledetekcji, 23, 365-376.

Rozporządzeniu Ministra Infrastruktury z dnia 15.07.2003 r.

Ustawa Prawo lotnicze z dnia 3 lipca 2002 r. Art. 126, pkt. 1. (Dz.U. z 2002 r. Nr 130, poz. 1112 z późn. $z m$.).

http://sjp.pwn.pl/poradnia/haslo/dron-czy-drona;12666.html (15.05.2017r.)

http://www.swiatdronow.pl/slownik (15.05.2017r.)

http://www.softx.pl 
Dr inż. Izabela Piech

University of Agriculture in Krakow

Department of Land Surveying, Cadastre and Photogrammetry

30-198 Kraków, ul. Balicka 253a

e-mail: rmpiech@cyf-kr.edu.pl

ORCID: 0000-0002-6710-4387

Inż. Artur Borgiasz

University of Agriculture in Krakow

Department of Land Surveying, Cadastre and Photogrammetry

30-198 Kraków, ul. Balicka 253a

e-mail: artur.borgiasz@gmail.com 